\title{
Reduced Fusarium Ear Rot and Symptomless Infection in Kernels of Maize Genetically Engineered for European Corn Borer Resistance
}

\author{
G. P. Munkvold, R. L. Hellmich, and W. B. Showers
}

First author: Department of Plant Pathology, 351 Bessey Hall, Iowa State University, Ames 50011; second author: USDA-ARS Corn Insects and Crop Genetics Research Unit and Department of Entomology, 109 Genetics Lab, Iowa State University, Ames 50011; and third author: Department of Entomology, Iowa State University, Ames 50011. Accepted for publication 11 July 1997.

\begin{abstract}
Munkvold, G. P., Hellmich, R. L., and Showers, W. B. 1997. Reduced Fusarium ear rot and symptomless infection in kernels of maize genetically engineered for European corn borer resistance. Phytopathology 87: 1071-1077.

Field experiments were conducted in 1994, 1995, and 1996 to evaluate the incidence and severity of Fusarium ear rot and the incidence of symptomless Fusarium infection in kernels of maize hybrids genetically engineered with Bacillus thuringiensis genes encoding for the $\delta$-endotoxin CryIA(b). Treatments included manual infestation with European corn borer (ECB) larvae and insecticide applications to limit ECB activity to specific maize growth stages or mimic standard ECB control practices. Fusarium symptoms and infection were affected by the specific cryIA(b) transformation used in each hybrid that determines tissue-specific ex-

kernel infection were reduced compared with near-isogenic hybrids lacking $\operatorname{cryIA}(b)$ genes. In plants that were manually infested with ECB, ear rot incidence was reduced by 87,58 , and $68 \%$; severity was reduced by 96, 54, and 64\%; and incidence of kernel infection by Fusarium species was reduced by 17,38 , and $38 \%$ in 1994, 1995, and 1996, respectively. Results were similar in treatments that were not manually infested, but differences between transgenic and nontransgenic hybrids were smaller. Most kernel infection was due to $F$. moniliforme, $F$. proliferatum, and $F$. subglutinans (section Liseola) collectively, and it was within this group that transgenic hybrids exhibited reduced infection. Expression of CryIA(b) in plant tissues other than kernels did not consistently affect Fusarium symptoms or infection. Disease incidence was positively correlated with ECB damage to kernels. Insecticide applications also reduced Fusarium symptoms and infection when applied to nontransgenic plants.
\end{abstract} pression of CryIA(b). In hybrids expressing CryIA(b) in kernels, incidence and severity of Fusarium ear rot and incidence of symptomless

Species of Fusarium Link are among the most common fungal associates of maize plants, causing diseases of seedlings, roots, stalks, and kernels (15). In Iowa, the most common species infecting maize kernels are $F$. graminearum Schwabe, $F$. moniliforme J. Sheld., F. proliferatum (T. Matsushima) Nirenberg, and $F$. subglutinans (Wollenweb. \& Reinking) P.E. Nelson, T.A. Toussoun, \& Marasas (25). The teleomorph of F. graminearum is Gibberella zeae (Schwein.) Petch (27), whereas the other species have a teleomorph in the G. fujikuroi (Sawada) Ito in Ito \& K. Kimura complex and are grouped in Fusarium section Liseola $(18,27)$. The disease on maize ears caused by $F$. graminearum is commonly known as Gibberella ear rot, and that caused by the members of section Liseola is known as Fusarium ear or kernel rot. There are a number of pathways by which Fusarium species may infect kernels, resulting either in kernel rot or symptomless infection $(2,11,24,34)$. Incidence of symptomless infection is usually higher than incidence of kernel rot $(11,24,33)$. Kernel infection by any of these fungi can reduce yields and quality, and result in mycotoxin accumulation in grain $(15,20)$.

The recent discovery of the fumonisins has enhanced concern over the widespread occurrence of Fusarium species in maize ker-

Corresponding author: G. P. Munkvold; E-mail address: munkvold@iastate.edu

Product names are necessary to report factually on available data; however, neither the USDA nor Iowa State University guarantees or warrants the standard of the product, and the use of the names implies no approval of the product to the exclusion of others that may be suitable.

Publication no. P-1997-0902-01R

This article is in the public domain and not copyrightable. It may be freely reprinted with customary crediting of the source. The American Phytopathological Society, 1997.
Additional keywords: Bt-toxin, corn, Gibberella. nels. Fumonisins are a class of mycotoxins that are produced primarily by some strains of $F$. moniliforme and $F$. proliferatum (26). Most prolific fumonisin-producing strains are found in mating populations A and D of G. fujikuroi, which, as currently described, is the teleomorph for both $F$. moniliforme (A) and $F$. proliferatum (D) (18). These compounds cause fatal diseases in horses and swine and cancer in laboratory rats. Esophageal cancer in humans has been associated with consumption of maize with high concentrations of the fumonisins $(19,28)$. Fumonisins can be detected in maize kernels with Fusarium symptoms and in symptomless infected kernels (2, $22,25,26,28)$.

Insect activity has long been associated with Fusarium infection of maize kernels and stalks (13). Injuries to plants caused by insects such as the European corn borer (ECB) (Ostrinia nubilalis) are often the initial infection sites for Fusarium species $(4,5,14)$. ECB larvae can act as vectors of $F$. moniliforme, carrying the fungus from plant surfaces into maize ears. ECB infestations can increase symptoms of Fusarium ear rot, as well as increase symptomless kernel infection (33). O. nubilalis has two generations per year in Iowa, and it is the second generation that can damage maize ears (31). Other insects may also cause entry wounds or act as vectors for Fusarium species, including corn earworms (32), corn rootworm beetles $(10)$, picnic beetles $(1,7,15)$, and thrips (8).

CryIA(b) is one of a group of $\delta$-endotoxins produced by some strains of a bacterium, Bacillus thuringiensis. These toxins are fatal to certain insects, particularly those in the order Lepidoptera (12). Genes encoding for CryIA(b) have been cloned and inserted into the genome of several crop plant species including maize $(9,16$, 17). Maize genotypes with this gene insertion have demonstrated a high level of resistance to $\operatorname{ECB}(3,16)$ and first became commercially available in 1996. Because of the close association between ECB damage and Fusarium infection, we hypothesized that 
these genotypes are subject to lower incidence of infection by these fungi. The expression of CryIA(b) in specific maize plant tissues is dependent on the gene promoter used in each transgenic genotype (16). The maize genotypes included in this study differ in the expression of CryIA(b) in kernel tissue. Proprietary cryIA(b) transformations MON810 and BT11 (both marketed as YieldGard; Monsanto Co., St. Louis) utilize a CaMV 35S gene promoter that results in season-long expression of CryIA(b) in all plant tissues, whereas cryIA(b) transformation 176 (marketed as Maximizer; Ciba Seeds, Greensboro, NC [currently Novartis Seeds, Minneapolis, MN]; and NatureGard; Mycogen Corp., San Diego, CA) utilizes a combination of two maize-derived, tissue-specific promoters: a phosphoenolpyruvate carboxylase (PEPC) promoter that results in gene expression only in green plant tissues, and a pollen-specific promoter (16). Kernel expression of CryIA(b) is likely to affect the extent of kernel feeding by ECB larvae and, subsequently, the intensity of Fusarium infection.

The objective of this research was to determine whether kernels of maize genotypes genetically engineered to express CryIA(b) have altered incidence and severity of Fusarium ear rot, altered incidence of symptomless infection by Fusarium species, or both. Preliminary results have been reported (23).

\section{MATERIALS AND METHODS}

Field experiments were conducted in 1994, 1995, and 1996 to evaluate the performance of maize hybrids genetically engineered with $B$. thuringiensis genes encoding for production of CryIA(b). In each experiment, transgenic hybrids were compared with nearisogenic maize hybrids lacking $\operatorname{cry} I A(b)$ genes. Near-isogenic hybrids were supplied by cooperating seed companies and were either identical (except for the cryIA $(b)$ genes) or very closely related to their corresponding transgenic hybrids. Experiments were arranged in randomized complete block designs. Plot size was $9.15 \mathrm{~m}$ or $6.1 \mathrm{~m}$ by four rows (approximately 40 or 26 plants per row), and row spacing was $0.76 \mathrm{~m}$. Only the middle two rows of each plot were treated and analyzed. There were $3.05-\mathrm{m}$ or $1.5-\mathrm{m}$ fallow alleyways between replicate blocks. In 1994, insecticidal treat-

TABLE 1. Maize hybrids included in field experiments examining the effects of CryIA(b) expression by maize hybrids on Fusarium infection of kernels

\begin{tabular}{|c|c|c|c|}
\hline Experiment & Hybrid & $\begin{array}{l}c r y I A(b) \\
\text { transformation }\end{array}$ & $\begin{array}{l}\text { CryIA(b) } \\
\text { expression in } \\
\text { kernels }\end{array}$ \\
\hline \multirow[t]{2}{*}{1994} & 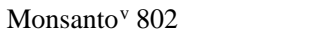 & MON810 & Yes \\
\hline & B73/Mo17 & None & No \\
\hline \multirow[t]{3}{*}{ 1995A } & Monsanto $^{\mathrm{v}} 802$ & MON810 & Yes \\
\hline & Monsanto $^{\mathrm{V}} 810$ & MON810 & Yes \\
\hline & B73/Mo17 & None & No \\
\hline \multirow[t]{4}{*}{ 1995B } & Northrup King ${ }^{\mathrm{w}}$ 6534CBR & BT11 & Yes \\
\hline & Northrup King ${ }^{w}$ X6514 & None & No \\
\hline & Northrup King ${ }^{w}$ X7634CBR & BT11 & Yes \\
\hline & Northrup King ${ }^{\mathrm{w}}$ X7514 & None & No \\
\hline \multirow[t]{4}{*}{$1995 \mathrm{C}$} & Mycogen $^{x}$ X5706Bt & 176 & No \\
\hline & Mycogen $^{\mathrm{x}} 7050 \mathrm{cb}^{\mathrm{y}}$ & None & No \\
\hline & Mycogen $^{x}$ X5821Bt & 176 & No \\
\hline & Mycogen $^{\mathrm{x}}$ X4820 & None & No \\
\hline \multirow[t]{8}{*}{1996} & Monsanto $^{\vee} 810$ & MON810 & Yes \\
\hline & B73/Mo17 & None & No \\
\hline & $\mathrm{Ciba}^{z} \mathrm{MAX} 454$ & 176 & No \\
\hline & Ciba $^{z} 4494$ & None & No \\
\hline & Mycogen $^{\mathrm{x}}$ NG7059BT & 176 & No \\
\hline & Mycogen $^{\mathrm{x}} 7050 \mathrm{cb}^{\mathrm{y}}$ & None & No \\
\hline & Northrup King ${ }^{\mathrm{w}}$ X6534CBR & BT11 & Yes \\
\hline & Northrup King ${ }^{\mathrm{w}}$ N6800 & None & No \\
\hline
\end{tabular}

\footnotetext{
${ }^{v}$ Monsanto Co., St. Louis.

${ }^{\text {w }}$ Northrup King Co., Golden Valley, MN.

x Mycogen Corp., San Diego, CA.

y Hybrid with naturally occurring resistance to European corn borer.

${ }^{\text {z }}$ Ciba Seeds, Greensboro, NC.
}

ments were included to limit ECB activity to specific plant growth stages. This approach was considered unnecessary in subsequent years. Additional hybrids were included as more transgenic hybrids became available.

In 1994, an experiment was planted on 14 May at the Iowa State University (ISU) Woodruff Farm in Story County, IA. There were two maize hybrids (Table 1) (Monsanto Co.) and seven treatments involving insecticide applications, manual ECB infestation (Table 2 ), or both, with six replicate blocks. Insecticide treatments were designed either to limit ECB activity to specific maize growth stages or to mimic standard ECB control practices, which typically involve two foliar insecticide applications, one prior to tasseling and one following pollination. Manual infestations were intended to mimic first-generation (growth stage V10 to V12 [29]) and secondgeneration (growth stage R1 [29]) ECB infestation (31). Manual infestations were conducted by using a volumetric dispenser to drop approximately 50 neonatal ECB larvae into the whorl (stage V10 to V12) or ear-leaf axil (stage R1) of each plant. Only the nontransgenic hybrid received the standard insecticidal treatments, because these would not be applied to transgenic hybrids in a production situation and would not add to the interpretation of our results.

Three experiments were conducted in 1995. Experiment 1995A, planted at the ISU Woodruff Farm on 22 May, involved three maize hybrids (Table 1) (Monsanto Co.) and four treatments involving ECB infestation, insecticide treatment (Table 2), or both, with six replicate blocks. Both hybrids did not receive all four treatments. Experiment 1995B included only hybrids developed by Northrup King Co. (Golden Valley, MN); there were four hybrids (Table 1) and no insecticide treatments, with four replicate blocks. All plots were manually infested with ECB larvae at stages V10 to V12 and R1. Experiment 1995C involved only hybrids developed by Mycogen Corp. (San Diego, CA); there were four hybrids (Table 1) and two insecticide treatments, with the nontransgenic hybrids (Table 2). All plots were manually infested with ECB larvae at stages V10 to V12 and R1.

In 1996, an experiment was planted on 13 and 14 May at the ISU Johnson Farm in Story County, IA; the experiment included eight hybrids from several seed companies (Table 1), no insecticide treatments, and two ECB infestation treatments (Table 2), with five replicate blocks.

TABLE 2. Insecticide and European corn borer (ECB) infestation treatments in field experiments with genetically engineered maize hybrids near Ames, IA, in 1994, 1995, and 1996

\begin{tabular}{|c|c|c|c|}
\hline Exp. & Treatment & Insecticide & ECB infestation \\
\hline \multirow{7}{*}{1994} & 1 & None & $\mathrm{V} 10$ to $\mathrm{V} 12^{\mathrm{s}}$ and $\mathrm{R} 1^{\mathrm{t}}$ \\
\hline & 2 & Pounce $1.5 \mathrm{G}^{\mathrm{u}}$ weekly, stage VT to R4 & $\mathrm{V} 10$ to $\mathrm{V} 12^{\mathrm{s}}$ \\
\hline & 3 & Pounce $1.5 \mathrm{G}^{\mathrm{u}}$ weekly, stage VE to V15 & $\mathrm{R} 1^{\mathrm{t}}$ \\
\hline & 4 & None & Natural \\
\hline & 5 & Dipel $10 \mathrm{G}^{\mathrm{v}}, 5$ days after infestations & $\mathrm{V} 10$ to $\mathrm{V} 12^{\mathrm{s}}$ and $\mathrm{R} 1^{\mathrm{t}}$ \\
\hline & 6 & Pounce $1.5 \mathrm{G}^{\mathrm{u}}, 5$ days after infestations & $\mathrm{V} 10$ to $\mathrm{V} 12^{\mathrm{s}}$ and $\mathrm{R} 1^{\mathrm{t}}$ \\
\hline & 7 & Pounce $1.5 \mathrm{G}^{\mathrm{u}}$ weekly, stage VE to $\mathrm{R} 4$ & Natural \\
\hline \multirow[t]{4}{*}{$1995 \mathrm{~A}$} & 1 & None & $\mathrm{V} 10$ to $\mathrm{V} 12^{\mathrm{w}}$ and $\mathrm{R} 1^{\mathrm{x}}$ \\
\hline & 2 & None & Natural \\
\hline & 3 & Pounce $1.5 \mathrm{G}^{\mathrm{u}}$ on 11 August & Natural \\
\hline & 4 & Dipel $10 \mathrm{G}^{\mathrm{v}}$ on 11 August & Natural \\
\hline 1995B & 1 & None & $\mathrm{V} 10$ to $\mathrm{V} 12^{\mathrm{w}}$ and $\mathrm{R} 1^{\mathrm{x}}$ \\
\hline \multirow[t]{2}{*}{$1995 \mathrm{C}$} & 1 & None & $\mathrm{V} 10$ to $\mathrm{V} 12^{\mathrm{w}}$ and $\mathrm{R} 1^{\mathrm{x}}$ \\
\hline & 2 & Pounce $1.5 \mathrm{G}^{\mathrm{u}}$, pretassel and postpollination & $\mathrm{V} 10$ to $\mathrm{V} 12^{\mathrm{w}}$ and $\mathrm{R} 1^{\mathrm{x}}$ \\
\hline \multirow[t]{2}{*}{1996} & 1 & None & Natural \\
\hline & 2 & None & $\mathrm{V} 10$ to $\mathrm{V} 12^{\mathrm{y}}$ and $\mathrm{R} 1^{\mathrm{z}}$ \\
\hline
\end{tabular}

s Conducted 30 June and 1 July. Growth stages according to Ritchie et al. (29).

t Conducted 20 and 21 July.

u $1.5 \%$ active ingredient, permethrin, applied at $0.56 \mathrm{~kg}$ of formulated product $/ \mathrm{ha}$. v $0.32 \%$ active ingredient, Bacillus thuringiensis kurstaki, applied at $14.6 \mathrm{~kg}$ of formulated product/ha.

${ }^{\mathrm{w}}$ Conducted 3, 5, and 6 July.

${ }^{x}$ Conducted 1 and 2 August.

y Conducted 5 and 9 July.

${ }^{\mathrm{z}}$ Conducted 30 and 31 July. 
In each experiment, 10 arbitrarily selected ears per plot were visually evaluated in the field for Fusarium ear rot, Gibberella ear rot, and insect damage to kernels. Data were recorded as the number of kernels displaying symptoms on each ear. Ear rot incidence was calculated as the percentage of plants per plot with symptoms of Fusarium or Gibberella ear rot. Ear rot severity was calculated as the mean number of kernels with symptoms per ear. Linear correlation coefficients were calculated for the relationship between incidence of Fusarium ear rot and incidence of ECB damage to ears (SigmaStat; Jandel Scientific, San Diego, CA).

Thirty ears (including those evaluated for disease and insect damage) were harvested from each plot and the kernels removed by hand or by an electric sheller. Kernels from each plot were thoroughly mixed, and 50 symptomless kernels were selected arbitrarily, surface-disinfested for $3 \mathrm{~min}$ in a $0.5 \%$ solution of sodium hypochlorite, and cultured on Nash-Snyder medium (27) for isola-

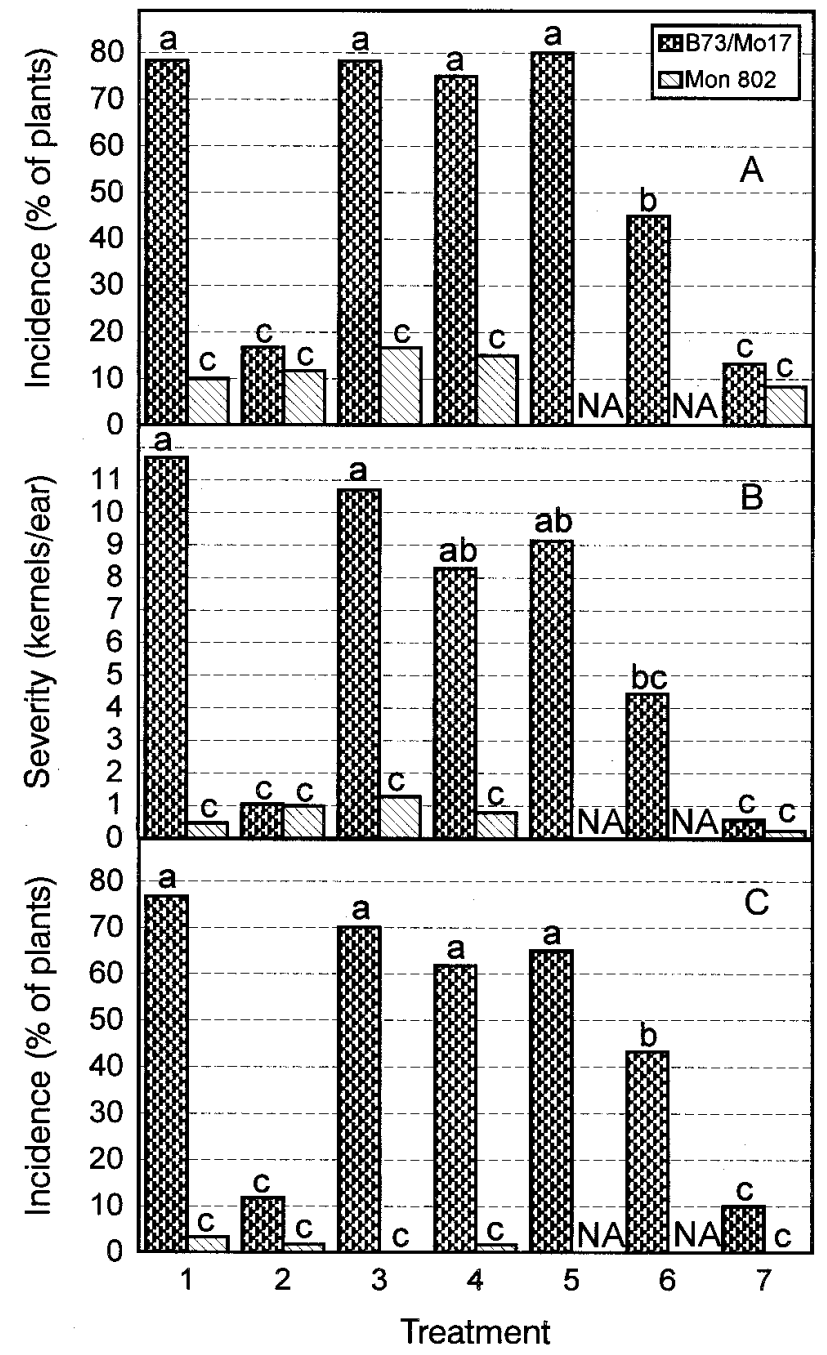

Fig. 1. A, Incidence and B, severity of Fusarium ear rot; and C, incidence of European corn borer (ECB) damage to ears in standard (B73/Mo17) and transgenic maize hybrids (Mon 802) in the field in 1994. Treatment 1, plants were manually infested with 50 neonatal ECB larvae at stages V10 to V12 and at stage R1; treatment 2, an insecticide, Pounce 1.5G (active ingredient permethrin $1.5 \%)$, was applied weekly $(0.56 \mathrm{~kg} / \mathrm{ha})$ from stage VT to R4 and plants were manually infested with ECB larvae at stages V10 to V12 only; treatment 3 , Pounce $1.5 \mathrm{G}$ was applied weekly from stage VE to V15 and plants were manually infested at stage R1 only; treatment 4 , no insecticide or manual infestation; treatment 5, plants were manually infested at stages V10 to V12 and at stage R1 and Bacillus thuringiensis kurstaki (Dipel 10G, 0.32\% a.i.) was applied at $14.6 \mathrm{~kg} / \mathrm{ha} 5$ days after infestation; treatment 6 , plants were manually infested at stages V10 to V12 and at stage R1, and Pounce 1.5G was applied 5 days after infestation; and treatment 7, Pounce $1.5 \mathrm{G}$ was applied weekly from stage VE to R4. tion of Fusarium species. Culture dishes were incubated for 7 to 10 days and observed for the presence of Fusarium colonies, identified by colony and conidial morphology (27). Colonies were not always identified to species, but were classified as either F. graminearum; Fusarium sp., section Liseola; or "other Fusarium sp." The second designation included $F$. moniliforme, $F$. proliferatum, and $F$. subglutinans. The percentage of kernels infected with each species or group was recorded for each plot.

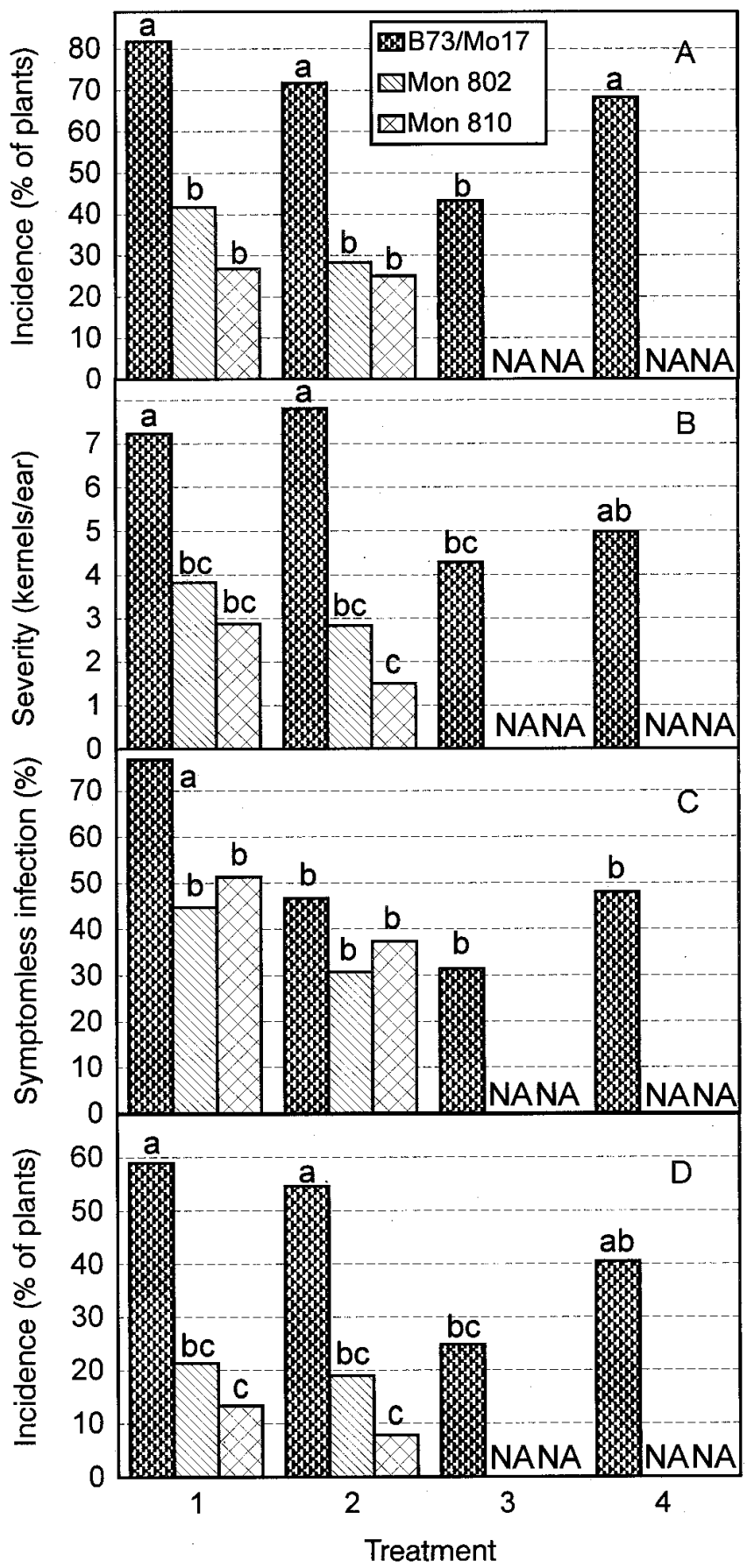

Fig. 2. Results of field experiment 1995A with standard (B73/Mo17) and transgenic (Mon 802 and Mon 810) maize hybrids. A, Incidence and B, severity of Fusarium ear rot; C, symptomless Fusarium infection of kernels; and D, incidence of European corn borer (ECB) damage to ears. Treatment 1, plants were manually infested with 50 neonatal ECB larvae at stages V10 to V12 and at stage R1; treatment 2, no manual infestation or insecticide; treatment 3, Pounce 1.5G (active ingredient permethrin 1.5\%) was applied on 11 August; and treatment 4, Dipel 10G (Bacillus thuringiensis kurstaki, 0.32\% a.i.) was applied on 11 August. 
Analyses of variance were conducted on Fusarium ear rot incidence and severity, incidence of symptomless kernel infection by Fusarium species, and ECB damage incidence and severity using the analysis of variance procedure of SigmaStat or the GLM procedure of SAS (SAS Institute, Cary, NC). Mean separation was determined by the Student-Newman-Keuls method (SigmaStat). Linear correlation analysis was conducted on data for all the dependent variables mentioned previously (SigmaStat).

\section{RESULTS}

There were significant differences in Fusarium ear rot incidence $(P \leq 0.0007)$ and severity $(P=0.0139$ to $P<0.0001)$ among treatments in each experiment (Figs. 1 to 3 ), except for disease incidence in experiment 1995C (Table 3). There was a close relationship between incidence and severity of Fusarium ear rot (Table 4). Manual infestation with ECB larvae increased disease incidence, whereas postpollination insecticide treatments or the presence of a

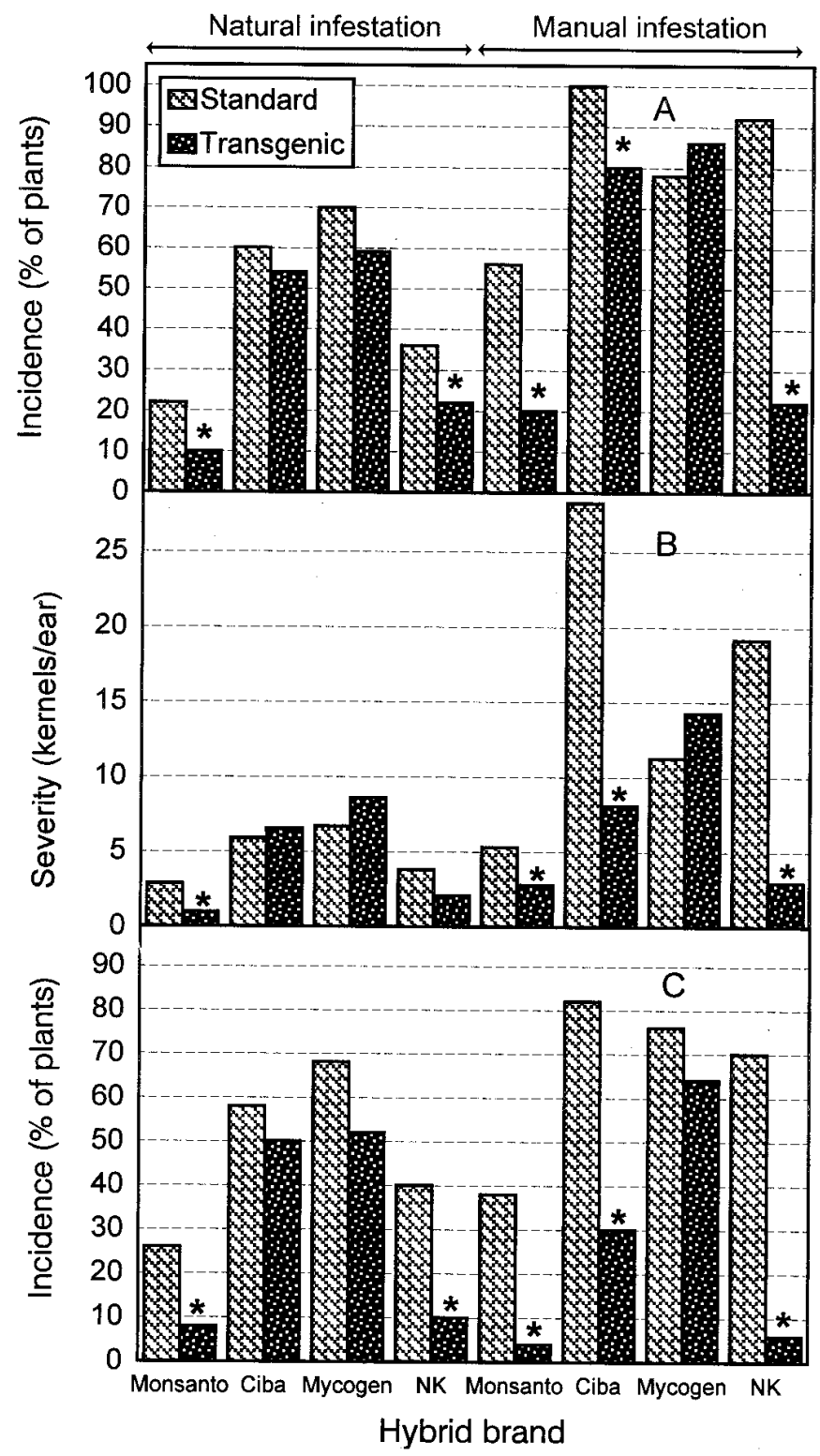

Fig. 3. Results of field experiment in 1996 with standard and transgenic maize hybrids. A, Incidence and B, severity of Fusarium ear rot; and C, incidence of European corn borer (ECB) damage to ears. Transgenic hybrids are paired with their near-isogenic counterparts. Manually infested plants were infested with 50 neonatal ECB larvae at stages V10 to V12 and at stage R1. * indicates a significant difference between standard and transgenic hybrids.
cryIA $(b)$ gene reduced disease incidence, except in experiment 1995C. When plants were manually infested with ECB, ear rot incidence was reduced by 87,58 , and $68 \%$, and severity was reduced by 96,54 , and $64 \%$ in $1994,1995 \mathrm{~A}$, and 1996, respectively, in transgenic hybrids that express CryIA(b) in kernels compared with their near-isogenic counterparts (Figs. 1 to 3 ). In treatments that were not manually infested with ECB larvae, differences between transgenic hybrids and nontransgenic hybrids were smaller. In transgenic hybrids not expressing CryIA(b) in kernels, reductions in incidence and severity were small or nonexistent (Fig. 3, Table 3). There was a significant correlation between incidence of Fusarium ear rot and incidence of ECB damage to ears in each experiment (Table 4), except experiment 1995C (Mycogen hybrids). Correlation coefficients were 0.88 in 1994, 0.53 in 1995A (Monsanto hybrid experiment), and 0.66 in $1996(P<0.0001$ for all three experiments). In the 1996 experiment, there were significant interactions among the effects of hybrid brand, presence of cryIA $(b)$ genes, and ECB infestation (Table 5). Incidence of Gibberella ear rot was negligible.

Incidence of symptomless Fusarium kernel infection ranged from 10 to $86 \%$ in the experiments. The linear correlation between disease severity and symptomless infection was poor, but significant (Table 4). The majority of Fusarium infection was due to species in section Liseola ( $F$. moniliforme, $F$. proliferatum, and $F$. subglutinans). Infection by other species, primarily $F$. graminearum,

TABLE 3. Kernel infection by Fusarium species in genetically engineered and near-isogenic Northrup King (experiment 1995B) and Mycogen (experiment 1995C) maize hybrids in separate field experiments near Ames, IA, in $1995^{y}$

\begin{tabular}{|c|c|c|c|c|}
\hline \multirow[b]{2}{*}{$\begin{array}{l}\operatorname{cry} I A(b) \\
\text { transformation }\end{array}$} & \multirow[b]{2}{*}{ Hybrid } & \multirow[b]{2}{*}{ Insecticide } & \multicolumn{2}{|c|}{ Fusarium ear rot } \\
\hline & & & $\begin{array}{c}\text { Incidence } \\
\text { (\% of plants) }\end{array}$ & $\begin{array}{c}\text { Severity } \\
\text { (kernels/ear) }\end{array}$ \\
\hline None & Northrup King X6514 & None & $85.0 \mathrm{a}$ & $11.1 \mathrm{a}$ \\
\hline BT11 & Northrup King 6534CBR & None & $40.0 \mathrm{bc}$ & $3.3 \mathrm{~b}$ \\
\hline None & Northrup King X7514 & None & $52.5 \mathrm{~b}$ & $3.7 \mathrm{~b}$ \\
\hline BT11 & Northrup King X7634CBR & None & $20.0 \mathrm{c}$ & $1.2 \mathrm{~b}$ \\
\hline None & Mycogen $7050 \mathrm{cb}$ & None & $100.0 \mathrm{a}$ & $19.6 \mathrm{a}$ \\
\hline 176 & Mycogen X5706Bt & None & $97.5 \mathrm{a}$ & $17.2 \mathrm{ab}$ \\
\hline None & Mycogen X4820 & None & $87.5 \mathrm{a}$ & $13.6 \mathrm{ab}$ \\
\hline 176 & Mycogen X5821Bt & None & $90.0 \mathrm{a}$ & $11.5 \mathrm{~b}$ \\
\hline None & Mycogen $7050 \mathrm{cb}$ & Pounce $2 x^{z}$ & $87.5 \mathrm{a}$ & $12.0 \mathrm{~b}$ \\
\hline None & Mycogen X4820 & Pounce $2 x^{Z}$ & $92.5 \mathrm{a}$ & $12.7 \mathrm{~b}$ \\
\hline
\end{tabular}

$\mathrm{y}$ Values are based on four replications of 10 ears each. Values in a column within each experiment followed by the same letter are not significantly different according to the Student-Newman-Keuls test $(\alpha=0.05)$. All plants were manually infested with 50 neonatal European corn borer larvae at growth stages V10 to V12 and R1.

${ }^{\mathrm{z}}$ Permethrin applied 5 days after each European corn borer infestation.

TABLE 4. Linear correlation coefficients among incidence and severity of Fusarium ear rot symptoms, symptomless Fusarium infection, and incidence and severity of European corn borer (ECB) damage to maize ears in field experiments conducted near Ames, IA, in 1994, 1995, and 1996

\begin{tabular}{cllccc}
\hline Year & \multicolumn{1}{c}{ Variable } & $\begin{array}{c}\text { Ear rot } \\
\text { severity }\end{array}$ & $\begin{array}{c}\text { Symptomless } \\
\text { infection }\end{array}$ & $\begin{array}{c}\text { ECB } \\
\text { incidence }\end{array}$ & $\begin{array}{c}\text { ECB } \\
\text { severity }\end{array}$ \\
\hline 1994 & Ear rot incidence & $0.769^{* * z}$ & $0.369^{* *}$ & $0.882^{* *}$ & $0.842^{* *}$ \\
& Ear rot severity & & $0.302^{* *}$ & $0.759^{* *}$ & $0.799^{* *}$ \\
& Symptomless infection & & & $0.398^{* *}$ & $0.391^{* *}$ \\
& ECB incidence & & & & $0.967^{* *}$ \\
1995 & Ear rot incidence & $0.822^{* *}$ & $0.391^{*}$ & $0.534^{* *}$ & $0.522^{* *}$ \\
& Ear rot severity & & $0.303^{*}$ & $0.438^{* *}$ & $0.468^{* *}$ \\
& Symptomless infection & & & $0.361^{*}$ & $0.345^{*}$ \\
& ECB incidence & & & & $0.957^{* *}$ \\
1996 & Ear rot incidence & $0.754^{* *}$ & $0.270^{*}$ & $0.662^{* *}$ & $0.639^{* *}$ \\
& Ear rot severity & & $0.297^{*}$ & $0.549^{* *}$ & $0.657^{* *}$ \\
& Symptomless infection & & & $0.255^{*}$ & $0.289^{*}$ \\
& ECB incidence & & & $0.841^{* *}$ \\
\hline
\end{tabular}

$\mathrm{z} *=$ correlation significant at $P \leq 0.05 ; * *=$ correlation significant at $P \leq 0.01$. 
was higher in 1994 than in the other years, probably because of cooler weather in 1994. Some kernels were infected with more than one Fusarium species. In 1995, infection by F. graminearum was not detected. In 1994, both total Fusarium infection and section Liseola infection were reduced in Monsanto 802 compared with B73/Mo17; a similar effect occurred when B73/Mo17 was sprayed with Pounce (permethrin) at pollination to control secondgeneration ECB larvae (Fig. 4). Manual ECB infestation increased total Fusarium incidence and section Liseola incidence in kernels in 1995 and 1996, but not in 1994 (Figs. 2, 4, and 5). Incidence of kernel infection by other Fusarium species had an inverse relationship with section Liseola incidence; therefore, Monsanto 802 and the insecticide-treated plots had higher incidences of other Fusarium species. Results were similar in 1995, except that infection by Fusarium species other than those in section Liseola was negligible and was not recorded. Maize hybrid Monsanto 810, also genetically engineered, had infection incidences similar to Monsanto 802 (Fig. 2). In plants that were manually infested with ECB, incidence of kernel infection by Fusarium species was reduced by 17,38 , and $38 \%$ in 1994, 1995A, and 1996, respectively, in transgenic hybrids that express CryIA(b) in kernels compared with their near-isogenic counterparts (Figs. 2, 4, and 5). Kernel infection was not reduced in hybrids that do not express CryIA(b) in kernels (Fig. 5). Results were similar in treatments that were not manually infested with ECB larvae. In the 1996 experiment, there were significant effects of brand, presence of a cryIA $(b)$ gene, and ECB infestation on incidence of kernel infection (Fig. 5, Table 5). There also were significant interactions among these factors (Table 5). In general, presence of a cryIA $(b)$ gene decreased infection and manual ECB infestation increased infection, but the effect depended on the maize hybrid.

Hybrids expressing CryIA(b) in kernels exhibited significantly less $(P \leq 0.05)$ kernel damage by ECB larvae compared with their nontransgenic counterparts (Figs. 1 to 3 ). In transgenic hybrids that do not express CryIA(b) in kernels, incidence of ECB damage to kernels was lower than in the nontransgenic hybrids, but a significant difference occurred only for one hybrid (Fig. 3).

\section{DISCUSSION}

This research has shown that transgenic maize hybrids with cryIA(b) genes that are expressed in kernels consistently exhibit reduced Fusarium ear rot and Fusarium infection of kernels compared with their nontransgenic counterparts. CryIA(b) expression in kernels resulted in greatly reduced kernel damage by ECB larvae, thereby eliminating an important pathway for infection by $F$. moniliforme. We recorded reductions in symptomless infection, as well as visible kernel rot, because ECB activity contributes to both types of infection (33).

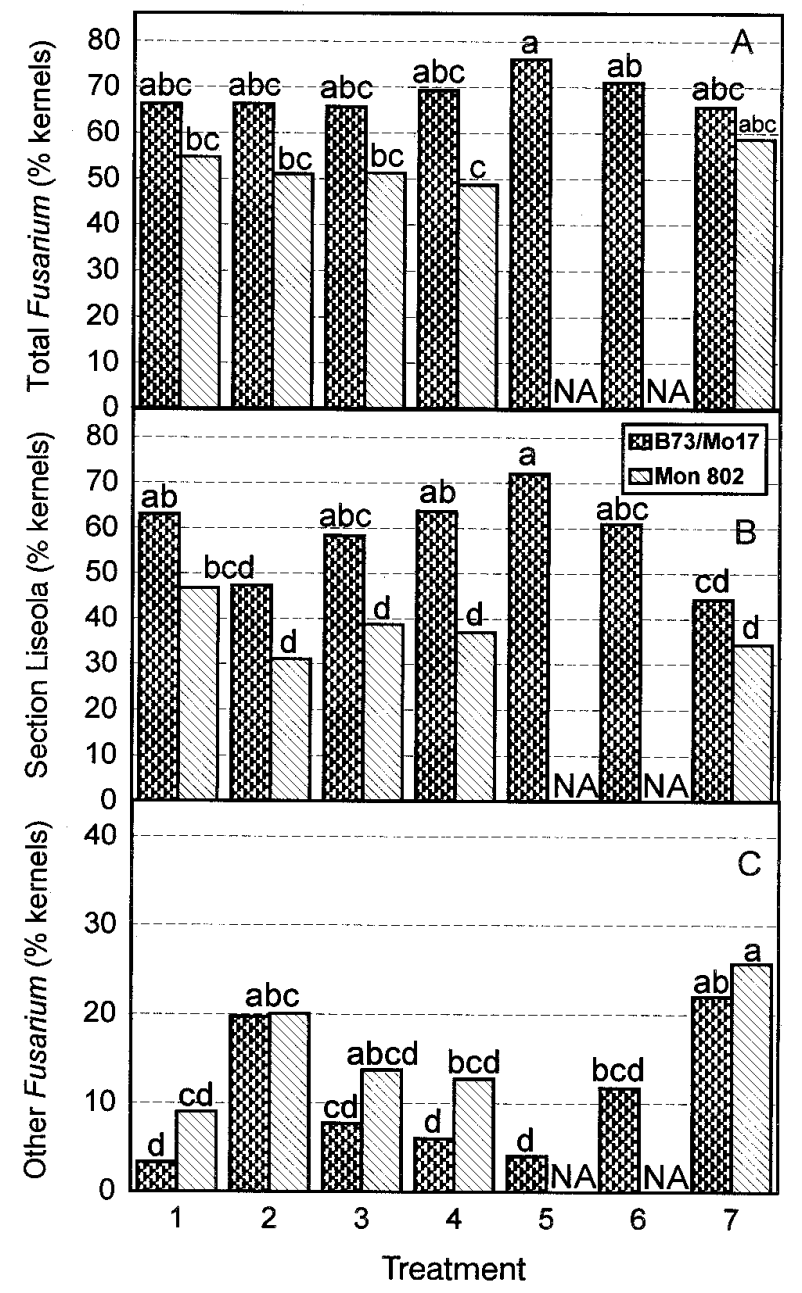

Fig. 4. Incidence of symptomless Fusarium infection in standard (B73/Mo17) and transgenic maize hybrids (Mon 802) in the field in 1994. A, All Fusarium species; B, species in section Liseola; and $\mathbf{C}$, other Fusarium species (primarily F. graminearum). Treatment 1, plants were manually infested with 50 neonatal European corn borer (ECB) larvae at stages V10 to V12 and at stage R1; treatment 2, an insecticide, Pounce $1.5 \mathrm{G}$ (active ingredient permethrin $1.5 \%$ ), was applied weekly $(0.56 \mathrm{~kg} / \mathrm{ha})$ from stage VT to R4 and plants were manually infested with ECB larvae at stages V10 to V12 only; treatment 3, Pounce 1.5G was applied weekly from stage VE to V15 and plants were manually infested at stage R1 only; treatment 4 , no insecticide or manual infestation; treatment 5 , plants were manually infested at stages V10 to V12 and at stage R1, and Bacillus thuringiensis kurstaki (Dipel 10G, $0.32 \%$ a.i.) was applied at $14.6 \mathrm{~kg} / \mathrm{ha} 5$ days after infestation; treatment 6, plants were manually infested at stages V10 to V12 and at stage R1, and Pounce $1.5 \mathrm{G}$ was applied 5 days after infestation; and treatment 7, Pounce $1.5 \mathrm{G}$ was applied weekly from stage VE to R4.

TABLE 5. $P$ values for the effects of hybrid brand, presence of $\operatorname{cryIA}(b)$ gene, and European corn borer (ECB) infestation on Fusarium kernel rot incidence, Fusarium kernel rot severity, and incidence of symptomless kernel infection by Fusarium species in a field experiment near Ames, IA, in 1996

\begin{tabular}{|c|c|c|c|c|c|c|c|}
\hline \multirow[b]{2}{*}{ Effect } & \multicolumn{2}{|c|}{ Insect damage } & \multicolumn{2}{|c|}{ Fusarium kernel rot } & \multicolumn{3}{|c|}{ Symptomless Fusarium infection $^{\mathrm{u}}$} \\
\hline & Incidence $^{v}$ & Severityw $^{w}$ & Incidence $^{v}$ & Severity $^{\mathrm{w}}$ & Total & Liseola $^{\mathrm{x}}$ & Other ${ }^{y}$ \\
\hline Brand & 0.0001 & 0.0001 & 0.0001 & 0.0001 & 0.0001 & 0.0001 & 0.2204 \\
\hline $\operatorname{cry} I A(b)$ transformation & 0.0001 & 0.0001 & 0.0001 & 0.0001 & 0.0018 & 0.0015 & 0.1284 \\
\hline Block & 0.0001 & 0.3153 & 0.0046 & 0.5677 & 0.1857 & 0.2081 & 0.0208 \\
\hline Brand $\times$ cryIA $(b)$ transformation & 0.0057 & 0.0057 & 0.0003 & 0.0006 & 0.0033 & 0.0035 & 0.1916 \\
\hline Brand $\times$ ECB & 0.5681 & 0.0780 & 0.3103 & 0.0179 & 0.9053 & 0.8665 & 0.7202 \\
\hline
\end{tabular}

u Measured as the percentage of infected kernels, based on isolation from five replications of 50 kernels each.

${ }^{\mathrm{v}}$ Measured as the percentage of plants with symptoms, based on five replications of 10 plants each.

${ }^{w}$ Measured as the mean number of kernels with symptoms per ear, based on five replications of 10 plants each.

${ }^{\mathrm{x}}$ Includes F. moniliforme, F. proliferatum, and F. subglutinans.

y Primarily F. graminearum.

${ }^{\mathrm{z}}$ Plants were either manually infested with 50 neonatal ECB larvae (growth stages V10 to V12 and R1) or naturally infested. 
Transgenic hybrids with the 176 transformation did not consistently differ from their nontransgenic counterparts in terms of $\mathrm{Fu}$ sarium symptoms or infection. This is probably due to the lack of expression of CryIA(b) in kernel tissue. The 176 transformation event results in expression only in green tissues and pollen (16). Hybrids with this transformation had more kernel damage by ECB larvae than did the hybrids with MON810 and BT11 transformations, which express CryIA(b) in kernel tissue. An exception occurred in the Ciba hybrid (176 transformation) in 1996. In this case, expression of CryIA(b) in stalks and leaves significantly reduced Fusarium ear rot symptoms. The mechanism is uncertain, but CryIA(b) expression in leaves and stalks caused mortality of ECB larvae (data not shown). This mortality resulted in fewer larvae migrating to the ears and causing kernel damage compared with nontransgenic hybrids (Fig. 3). Under these conditions, there was a reduction in Fusarium symptoms without kernel expression of CryIA(b). However, there was a poor correlation in the Ciba hybrids

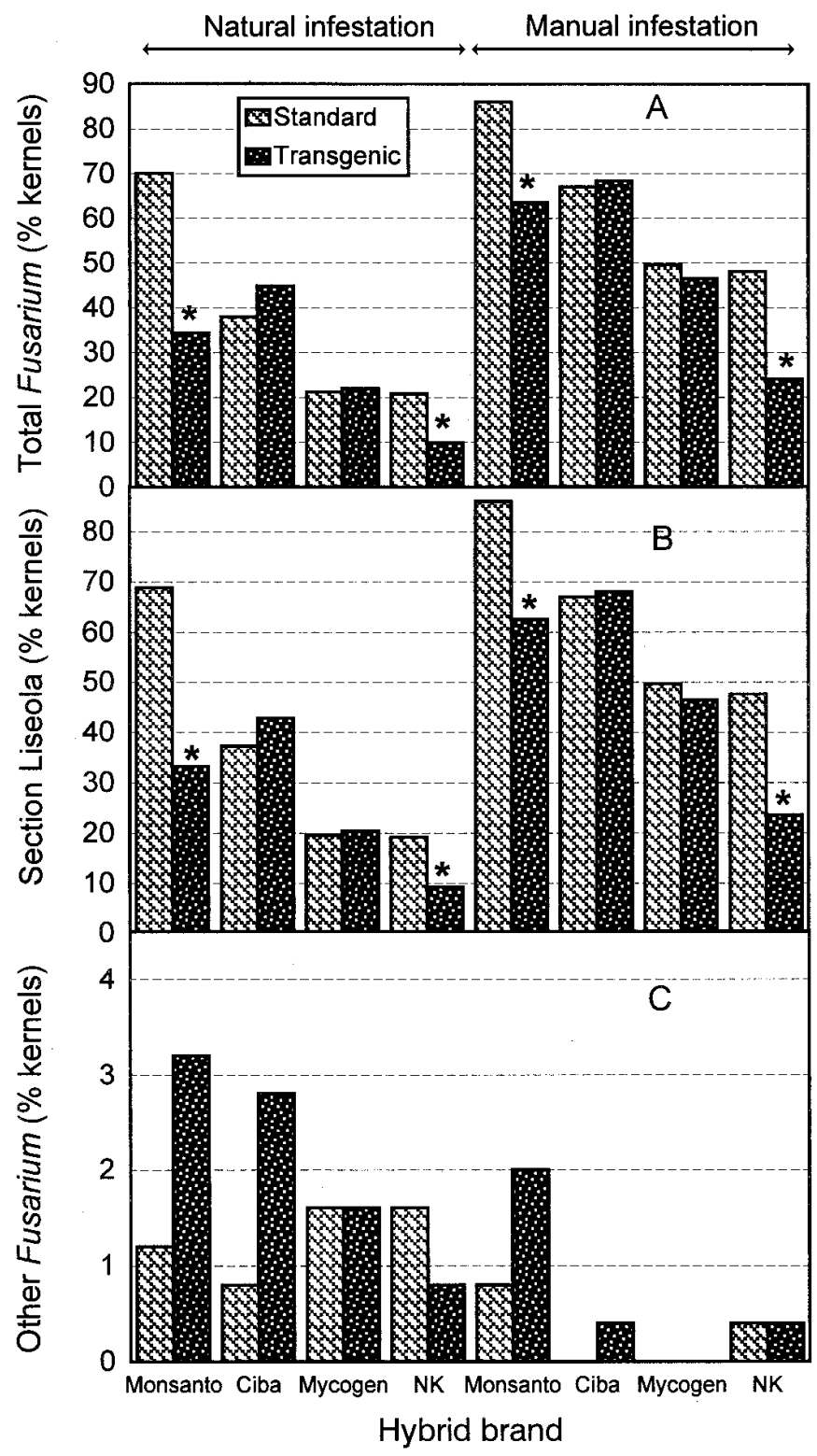

Fig. 5. Incidence of symptomless Fusarium infection in standard and transgenic maize hybrids in the field in 1996. A, All Fusarium species; B, species in section Liseola; and C, other Fusarium species (primarily F. graminearum). Transgenic hybrids are paired with their near-isogenic counterparts. Manually infested plants were infested with 50 neonatal European corn borer larvae at stages V10 to V12 and at stage R1. * indicates a significant difference between standard and transgenic hybrids. between ear rot symptoms and symptomless infection, which was higher in the transgenic hybrid.

Reduced Fusarium infection in transgenic genotypes resulted in better grain quality (less mold damage) and decreased potential for the development of fumonisins (as a result of lower disease severity and infection incidence). Reduced Fusarium infection also may result in higher seed quality in transgenic maize inbreds grown for seed production (21). Research on cotton indicates that significant reductions in mycotoxin concentrations can be achieved when insect-associated fungal diseases are partially controlled by transgenic insect resistance (6). Reduction in fumonisin concentrations could be a substantial benefit of CryIA(b) transgenic maize. Reduction of fumonisin concentrations might require decreases in both ear rot symptoms and symptomless infection, because fumonisins occur in symptomless kernels $(2,22,25,28)$, but higher concentrations usually occur in symptomatic kernels $(22,28)$. Physical damage to infected kernels promotes fumonisin development (30). Our data showed that ECB damage was more closely related to ear rot symptoms than to symptomless infection. Further research is needed to accumulate data on the effects of CryIA(b) expression on fumonisin concentrations under naturally occurring ECB populations, and on the occurrence of other maize diseases that are associated with, or exacerbated by, ECB damage.

\section{ACKNOWLEDGMENTS}

Journal paper J-17323 of the Iowa Agriculture and Home Economics Experiment Station, Ames, IA, Project 3260, supported by Hatch Act and State of Iowa funds. This research was partially supported by funds from Monsanto Co., and we thank Novartis Seeds and Mycogen Corp. for their cooperation. This is a joint contribution from USDA, Agricultural Research Service, and Iowa State University. We thank M. E. Rice for establishment of field experiments 1995B and 1995C. We also thank D. A. Bickett, B. S. Coates, J. M. Dyer, K. J. Heiar, C. T. Iverson, K. A. McNutt, J. K. O’Mara, C. D. Tate, S. L. Van Loon, D. H. Vercruysse, A. J. Vikemyr, and K. A. Walker for technical support.

\section{LITERATURE CITED}

1. Attwater, W. A., and Busch, L. V. 1983. Role of the sap beetle Glischrochilus quadrisignatus in the epidemiology of Gibberella corn ear rot. Can. J. Plant Pathol. 5:158-163.

2. Bacon, C. W., Bennett, R. M., Hinton, D. M., and Voss, K. A. 1992. Scanning electron microscopy of Fusarium moniliforme within asymptomatic corn kernels and kernels associated with equine leukoencephalomalacia. Plant Dis. 76:144-148.

3. Bauer, L. S. 1995. Resistance: A threat to the insecticidal crystal proteins of Bacillus thuringiensis. Fla. Entomol. 78:414-443.

4. Chiang, H. C., and Wilcoxson, R. D. 1961. Interactions of the European corn borer and stalk rot in corn. J. Econ. Entomol. 54:850-852.

5. Christensen, J. J., and Schneider, C. L. 1950. European corn borer (Pyrausta nubilalis Hbn.) in relation to shank, stalk, and ear rots of corn. Phytopathology 40:284-291.

6. Cotty, P. J., Howell, D. R., Bock, C., and Tellez, A. Aflatoxin contamination of commercially grown transgenic BT cottonseed. Pages 108-110 in: Proc. Beltwide Cotton Production Res. Conf. National Cotton Council of America, Memphis, TN.

7. Dowd, P. F. 1991. Nitidulids as vectors of mycotoxin-producing fungi. Pages 335-342 in: Aflatoxin in Corn: New Perspectives. North Central Region Research Publication 329. Iowa State University, Ames.

8. Farrar, J. J., and Davis, R. M. 1991. Relationships among ear morphology, western flower thrips, and Fusarium ear rot of corn. Phytopathology 81:661-666.

9. Fromm, M. E., Morrish, F., Armstrong, C., Williams, R., Thomas, J., and Klein, T. M. 1990. Inheritance and expression of chimeric genes in the progeny of transgenic maize plants. Bio/Technology 8:833-839.

10. Gilbertson, R. L., Brown, W. M., Jr., Ruppel, E. G., and Capinera, J. L. 1986. Association of corn stalk rot Fusarium spp. and western corn rootworm beetles in Colorado. Phytopathology 76:1309-1314.

11. Headrick, J. M., and Pataky, J. K. 1991. Maternal influence on the resistance of sweet corn lines to kernel infection by Fusarium moniliforme. Phytopathology 81:268-274.

12. Hofte, H., and Whiteley, H. R. 1989. Insecticidal crystal proteins of Bacillus thuringiensis. Microbiol. Rev. 53:242-255. 
13. Hopmans, E. C., and Murphy, P. A. 1993. Detection of fumonisins $B_{1}$, $\mathrm{B}_{2}$, and $\mathrm{B}_{3}$ and hydrolyzed fumonisin $\mathrm{B}_{1}$ in corn-containing foods. J. Agric. Food Chem. 41:1655-1658.

14. Jarvis, J. L., Clark, R. L., Guthrie, W. D., Berry, E. C., and Russell, W. A. 1984. The relationship between second-generation European corn borers and stalk rot fungi in maize hybrids. Maydica 29:247-263.

15. Kommedahl, T., and Windels, C. E. 1981. Root-, stalk-, and ear-infecting Fusarium species on corn in the USA. Pages 94-103 in: Fusarium: Diseases, Biology, and Taxonomy. P. E. Nelson, T. A. Toussoun, and R. J. Cook, eds. Pennsylvania State University Press, University Park.

16. Koziel, M. G., Beland, G. L., Bowman, C., Carozzi, N. B., Crenshaw, R., Crossland, L., Dawson, J., Desai, N., Hill, M., and Kadwell, S. 1993. Field performance of elite transgenic maize plants expressing an insecticidal protein derived from Bacillus thuringiensis. Bio/Technology 11:194-200.

17. Koziel, M. G., Carozzi, N. B., Currier, T. C., Warren, G. W., and Evola, S. V. 1993. The insecticidal crystal proteins of Bacillus thuringiensis: Past, present and future uses. Biotechnol. Genet. Eng. Rev. 11:171-228.

18. Leslie, J. F. 1995. Gibberella fujikuroi: Available populations and variable traits. Can. J. Bot. 73(suppl. 1):S282-S291.

19. Marasas, W. F. O. 1995. Fumonisins: Their implications for human and animal health. Natural Toxins 3:193-198.

20. Marasas, W. F. O., Nelson, P. E., and Toussoun, T. A. 1984. Toxigenic Fusarium Species: Identity and Toxicology. Pennsylvania State University Press, University Park.

21. McGee, D. C. 1988. Maize Diseases: A Reference Source for Seed Technologists. The American Phytopathological Society, St. Paul, MN.

22. Munkvold, G. P., and Desjardins, A. E. 1997. Fumonisins in maize: Can we reduce their occurrence? Plant Dis. 81:556-565.

23. Munkvold, G. P., Hellmich, R. L., Showers, W. B., and Rice, M. E. 1996. Gibberella infection in kernels of transgenic (Bt) maize. (Abstr.) Phytopathology 86:S47.

24. Munkvold, G. P., McGee, D. C., and Carlton, W. M. 1997. Importance of different pathways for maize kernel infection by Fusarium moniliforme. Phytopathology 87:209-217.

25. Munkvold, G. P., and Stahr, H. M. 1994. Ear rots and mycotoxins in Iowa corn. (Abstr.) Phytopathology 84:1064.

26. Nelson, P. E., Desjardins, A. E., and Plattner, R. D. 1993. Fumonisins, mycotoxins produced by Fusarium species: Biology, chemistry, and significance. Annu. Rev. Phytopathol. 31:233-252.

27. Nelson, P. E., Toussoun, T. A., and Marasas, W. F. O. 1983. Fusarium Species: An Illustrated Manual for Identification. Pennsylvania State University Press, University Park.

28. Rheeder, J. P., Marasas, W. F. O., Thiel, P. G., Sydenham, E. W., Shephard, G. S., and van Schalkwyk, D. J. 1992. Fusarium moniliforme and fumonisins in corn in relation to human esophageal cancer in Transkei. Phytopathology 82:353-357.

29. Ritchie, S. W., Hanway, J. J., and Benson, G. O. 1992. How a corn plant develops. Iowa State Univ. Extension Spec. Rep. 48.

30. Schaafsma, A. W., Miller, J. D., Savard, M. E., and Ewing, R. J. 1993. Ear rot development and mycotoxin production in corn in relation to inoculation method, corn hybrid, and species of Fusarium. Can. J. Plant Pathol. 15:185-192.

31. Showers, W. B., Witkowski, J. F., Mason, C. E., Calvin, D. D., Higgins, R. A., and Dively, G. P. 1989. European corn borer development and management. North Central Regional Publication 327. Iowa State University, Ames.

32. Smeltzer, D. G. 1958. Relationship between Fusarium ear rot and corn earworm infestation. Agron. J. 50:53-55.

33. Sobek, E. A. 1996. Associations between corn insects and symptomatic and asymptomatic corn kernel infection by Fusarium moniliforme. M.S. thesis. Iowa State University, Ames.

34. Thomas, M. D., and Buddenhagen, I. W. 1980. Incidence and persistence of Fusarium moniliforme in symptomless maize kernels and seedlings in Nigeria. Mycologia 72:882-887. 